\title{
Correction: Protecting medicine's wild pharmacy
}

Jim Kling

Nature Plants 2, 16064 (2016); published online 4 May 2016; corrected online 1 June 2016.

In version of this News article originally published, it was incorrectly stated that the FairWild project in the Bhimashankar Wildlife Sanctuary involving the Mahadev Koli tribal people focuses on the Terminalia bellirica tree and has implications for Malabar pied hornbill conservation. In fact, the FairWild project in the Bhimashankar Wildlife Sanctuary focuses on the Terminalia cherula tree, while a second FairWild project in the northwest Ghats region of India, not associated with the Mahadev Koli tribal people, involves Terminalia bellirica and the Malabar pied hornbills. This has now been corrected. 